\title{
The Journey of Truth: From Plato to Zola*
}

\author{
Ribut Basuki
}

\begin{abstract}
Western theater theory and criticism is generally considered to be set forth by the Greeks. Plato was "the first theater critic" with his negative comments about theater owing to his idealistic views about "the truth." Then came Aristotle who used a different viewpoint from that of Plato, saying that there is "truth" in theater. However, hostile criticism on theater came back in the Middle Ages, championed by Tertulian before Aristotelian theory was revived by the neo-classicists such as Scaliger and Castelvetro. Theater theory and criticism discourse was then made more alive by the romanticists who disagreed with the neo-classicists' rigid rules on theater. As the influence of science became dominant in the theater world, naturalism and realism emerged and became the mainstream of theater theory and criticism until well into the twentieth century.
\end{abstract}

Keywords: truth, theatre critics, dramatic theory, Plato, Aristotle, Romanticism, Neo-classic, realism, art, Horace, Longinus.

Truth, in all its manifestations, has always been the object of human inquiry. It has been the claim of religions and the obsession of philosophy, science and art. Theatre has dealt with truth as a part of its struggle for centuries, since the ancient time. The discussion of truth as a specific discourse in theatre, however, is more clearly seen in the dramatic theory and criticism than in the plays. Therefore, I will discuss the "journey" from the eyes of the "critics," although some of them were writers as well. Far from regarding this paper as a comprehensive discussion on the subject, given all the availability of sources and the limitation of space, this paper is more like a crude map of the journey. This journey will start from Plato and Aristotle, as the representatives of the ancient critics, to the romanticist represented by Stendhal and the naturalist represented by Zola.

Plato (427-347 B.C.) and Aristotle (384-322 B.C.) can be considered as the ones who set forth the debate about art as a form of imitation of life. As an idealist Plato believed that truth is in "the world of Ideas" that is permanent. The existence of all physical objects, therefore, is dependent on the mind. In other words, although the phenomenal is separated from the nouminal-which is why he is also called a dualist-, the phenomenal is dependent upon the nouminal. It is dependent in that it is an imitation of the nouminal, so that it is not a good source of knowledge. To Plato, art (in this case, theatre) is useless (and even harmful) since it is too far removed from the truth. The artists just "copy images of virtue and the like, but the truth they never reach" (Plato 24). Theatre is devoid of any truth since the artists do not have the access to reach it. Theatre is just "a bad lie" (Plato 14). Truth, to Plato, is only in the mind. Physical objects that are perceived by human senses are just the copy or the manifestation of

* This paper was supposed to be developed from selected essays edited by Bernard F. Dukore only. 
truth which Plato called it Form. The highest truth is the "ultimate Form" as a philosophical construct that gives light to all Forms.

Aristotle, having a very different world view from that of Plato, came with the idea that poetry and truth is closely related. Truth even lives within poetry, generating its "forward movement" to its final destiny. Truth functions as the "Prime Mover," or the "First Cause" or, in his own words, "the thought of thought." As a "living organism" (Aristotle 105), a tragedy moves forward with truth as its soul. Aristotle did not divide the nouminal and the phenomenal. His theory of imitation is, therefore, completely different from that of Plato. Instead of putting Form-reality-art linearly, Aristotle said that the artists "must of necessity imitate one of three objects-things as they were or are, things as they are said or thought to be, or things as they ought to be" (Aristotle 111). Using Plato's logic, by saying that artists are able to imitate "things as they ought to be" Aristotle put the linear Form-reality-art in a triangle so that in some ways the art has a direct access to Form/Truth.

In poetry (tragedy and comedy), the poet does not imitate human being as a static object. Aristotle contended that the poet imitates "men in action" (52). He further said, "Tragedy is an imitation, not of men, but of action and of life, and life consists in action, not a quality" (62). Action is, therefore, the basis of the Aristotelian imitation. Unlike Plato, truth functions more as a background or "the spirit" behind the imitation, not the purpose of the imitation.

By the time the tradition went to Horace of Rome (65-8 B.C.), truth is put in "Nature" (70). Unimaginative as they were (some critics say that the Roman were far less imaginative than the Greeks), the Roman saw life more in practical nature (even their gods are considered more practical than those of the Greeks, which are more philosophical). "Nature shapes first our inner thoughts to take the bent of circumstance," said Horace (70). Truth to Horace is what is logical or natural. A painter who "couple(s) a horse's neck with a man's head" (67) distorts truth in Horace's view, since it violates the idea of unity. A good poet should make a careful observation of nature (71), a consistent character (70), and natural depiction of object (68). Horace demanded that poetry as a imitation of life/Nature "consists of five acts-no more, no less" (71), thus introducing rules to poetry. All these ideas were then adopted by the neoclassicists.

Truth in Plato's sense was brought back to the theatre discourse by Longinus (1 ${ }^{\text {st }}$ or 3 A.D.), a Greek living under the Roman Empire. As a neo-platonic philosopher, Longinus believed in what is beyond human experience. Longinus referred to truth as "the Sublime." However, Longinus took a different bent to Plato's ideas. Instead of dealing with the accuracy of the imitation, he dealt with the idea of "transport" to "the Sublime" (76). Longinus still believed in "the guidance of knowledge" (77), but he put it differently either from Plato or from Horace. Unlike Plato who rejected feeling, Longinus believed in the "excellence of expression" (76) in which reason and feeling blends. Unlike Horace who emphasized more on observation of nature as the source of knowledge, he used knowledge in relation to "the Sublime." Longinus did not mind "inaccurate imitations." He said:

I have myself noted not a few errors on the part of Homer and other writers of the greatest distinction, and the slips they have made afford me anything but pleasure. Still I do not term them willful errors, but rather oversights of a random a casual kind, due to neglect and introduced with all heedlessness of genius. (81) 
Instead of paying too much attention to the accuracy, Longinus proposed that as long as the work is able to transport the audience to the lofty, it is a genius work. These ideas were later associated with the romanticists who glorified feeling.

Truth got a special place when Tertullian (155-220 A.D.) and Boccacio (1313-1375 A.D.) came to the fore. It perfectly fitted into the concept of the Judeo-Christian God which later influenced the Roman world. In their opinions about theatre, Tertulian and Boccacio remind us of Plato and Aristotle centuries earlier. Like Plato, Tertulian was hostile toward theatre, while Boccacio, although we cannot really compare him with Aristotle, "defended" theatre. Unlike the discussion of the ancient Greeks, however, the theatre had a new background: the Church and Christianity.

Tertulian claimed that his rejection to theatre has a deeper ground. While Plato believed that truth is in the conscious mind, Tertulian embraced the Judeo-Christian belief that truth is in God, who overcomes human being's mind. God is the Creator, nature and men are the creations. To Tertullian, theatre tends to make false picture of God's creation by showing the wicked. The issue, therefore, is about how any human creation should "please" God. He said: "We must not, then, consider by whom all things were made, ... We shall find out for what use they were made" (85). Since theatre derives from the worship of man made gods, "with reference to the origin of shows, every show is an assembly of the wicked ..." (87). Instead of just "truth," therefore, Tertullian introduced "the Truth." It differs from Plato's in that Plato talked about Form as the "model" of the a physical thing (thus, every thing has its own Form) before talking about the "ultimate Form." Tertullian talked about God as the "ultimate Truth" before anything else. In some ways, Tertullian put Plato's "ultimate Form" in the figure of God and Horace's "Nature" as God's creation. Plato's world of ideas is dropped from the discourse.

Tertullian realized that his claims in rejecting theatre are not written in the Scripture. To defend his opinion, he argued that it is implied:

Well, we never find it expressed with the same precision, "Thou shalt not enter circus or theatre, thou shalt not look on combat or show," ... But we find that the first word of David bears on this very sort of things: "Blessed," he says, "is the man who has not gone into to assembly of the impious, nor stood in the way of sinners, nor sat in the seat of scorners." (86)

The theatre, to Tertullian, is the house of sin and therefore Christians are forbidden to go. Most often the theatre mocks God even when they have characters like a priest (92). They make false imitations of God's creations, and "the Author of truth hates all the false; He regards as adultery all that is unreal" (92). While having the same disagreement about poetry, Tertullian and Plato differed in some respects. Plato's "ultimate Form" is still determined by human's mind, Tertullian's "ultimate Truth"/God overcomes human's mind. Plato's used Form as the ideal "model" of physical things (which is dependent on human's mind), Tertullian dropped it from the discourse. To Plato, a physical thing is the imitation of Form, to Tertullian it is God's creation. To Plato, art is an imitation too far removed from the Form, and to Tertullian, art is (often) false imitation of nature/God's creation.

While Tertulian was the representative of the prevailing medieval critics, Boccacio (1313-1375) was that of the new thinkers, the humanists, who later gave birth to the renaissance. Living in the medieval world-view Boccacio embraced the idea that the ultimate truth is in God. However, he also stipulated that human beings, with his efforts, can approach "the Truth." Unlike the medieval critics who had the tendency to 
emphasize "the after life," Boccacio and his humanist colleagues also celebrated life itself as well as accepting "the after life."

Poetry, to Boccacio, is a way to approach "the Truth." Therefore, unlike Tertulian, he considered poets as special people. To him, true poet has always been the rarest of men. (105) He regarded them as the wisest of men, provided that they have, like good Catholics, recognized the true God (104). Philosophically, Boccacio substituted Plato's "ultimate Form" to God, while human being's duty is to "attain the true knowledge of God" (105). (Traditionally, Christian philosophers use Platonic idealism to approach the understanding of God). Thus, Boccacio hailed poetry at the same position with philosophy and theology.

To convince others that poets are not liars, Boccacio presented four kinds of poetry that deal with truth. The first kind superficially lacks the appearance of truth, the second mingles fiction with truth, the third is more like a history, and the fourth contains no truth at all. Then, he argued that the Bible contains the first three kinds. With this understanding, poetry becomes a "method" to achieve a higher truth and finally the "ultimate Truth"/God (106-107). Boccacio also defended the pagan poets by saying that they told a falsehood out of ignorance. They did it because "that light of the eternal truth which lighteth every man that cometh into the world had not yet shone upon the nations" (109). "Such ignorance is an acceptable excuse," he said, "and they ought not to be called liars" (109). From this point we now see that there are two kinds of truth. The first is based on logic and human observation, the second is "the Truth" that we can associate with Plato's "ultimate Form" that has been adopted by Christian philosophers to depict God.

The renaissance in Italy came with the challenge to the domination of the church and the celebration of reason that was initiated by the humanists. A big paradigm shift happened. By this time, the theatre did not have to defend itself for its existence since there were no more "harsh, intolerant, and fierce" (Dukore 83) critics like Tertullian. Instead, the critics went directly to "the analysis" of poetry. To do so, they re-explored the classics, especially Aristotle and Horace. In doing so, these neoclassicists pushed the "ultimate Truth" to such a distance that it could hardly be seen.

From the neoclassicists like Scaliger (1484-1558) and Castelvetro (1505-1571) we see that the issue of imitation in the Italian renaissance was more about that of life. Truth in their discourse, therefore, was whether or not poetry is logical and "true to life" (Scaliger 143). They coined the terms unity of time, place, and action; verisimilitude; and decorum as the basic rules of "logical imitation" in poetry. Although they quote Aristotle a lot, they dropped his "thought of thought" from their discourse. They did mention "imitation of action" as Aristotle had done. However, instead of seeing it as the action that is generated from within, they saw it as it is observed from without. The neoclassicists, therefore, are closer to Horace than to Aristotle.

Scaliger still emphasized poetry as a means of instruction or persuasion (138-139), but the knowledge poetry should teach is no longer "the true knowledge of God" as Boccacio proposed. Knowledge to him is "belief based upon conclusive evidence ... (and) truth, in turn, is agreement between that which is said about a thing and the thing itself" (193). Thus, he leaves the "ultimate Truth" behind as the business of religion.

Castelvetro disagreed with Scaliger about the purpose of poetry. Thinking that he restored Aristotelian peotry, he argued that poetry is merely for pleasure. To him, the end of a tragedy is action, not moral (145). The poet's duty "is to imitate through speculation the reality of people caught in the accident of fortune"(143). Yet, while pushing morality—which was of course under Christianity's umbrella-away, 
Castelvetro also dropped the Aristotelian "movement of the spirit that is driven by the "prime cause" from his ideal poetry.

As neoclassicism started to flourish in Italy, theatre in England still faced existential problem like that in Italy a century earlier. The English Tertullians were, among others, John Northbrooke (16 th century) and Stephen Gosson (1554-1623). Northbrooke called the theatre as "Satan's banquets" and Gosson charged the theatre for the deterioration of England's manners and morals (Dokure 157). It is a place where the soul of the wise is snared and condemned, where people make filthy speeches, where whoredom begins and where people mishandle God's divine mystery (Northbrooke 16061). Gosson, a former actor and unsuccessful playwright (Dukore 157), needed to repent from his sin of being "in the school of abuse" for some time (162-66). Like Tertullian, they used theological "ultimate Truth" to judge the theatre.

Thomas Lodge (1558-1625) and Sir Philip Sidney (1554-1586) came to defend the English theatre. Lodge needed to mention Aristotle, Seneca, David, and Solomon to argue that poetry is not always harmful. Sidney made a more convincing defense than Lodge did when he discussed Plato. To him, Plato disagreed with "the abuse" of poetry, not poetry itself (174). He also interpreted Aristotle's idea of poetry as "to teach and to delight" (169). Interestingly, in the discussion of imitation Sidney mentioned about three kinds of "poet." The first and the chief are those who imitate "the unconceivable excellencies of God" (169), the second are those who "deal with matters philosophical" including moral, natural, astronomical, and historical (169), the third are those who "to imitate borrow nothing of what is, hath been, or shall be; but range only reined with learned discretion, into the divine consideration of what may and what should be" (170). Sidney categorized the first kind as "prophetic" like David or Solomon, the second as "philosophical" like Cato or Lucan, and the third as the poet who "popularize" the other two, using their artistic crafts. The poets are, to Sidney, "the popular philosopher(s)" (170). The truth in the English discourse, therefore, is theological, philosophical, and artistic at the same time.

In France and Spain theatre did not really suffer from the anti-theatre critics. The Church seemed to readily adopt the neoclassical thoughts that originated in Italy. In France, The neoclassical ideas were first adopted by the critics in French Academy under Cardinal Richelieu. Eager to make a French artistic standard of poetry, the Cardinal imposed rules to poetic correctness. Again, although under Christianity's background, the discussion of truth was more on the imitation of poetry to real life. From "Le Cid" controversy we can see how the issues of unity, verisimilitude, and decorum were the major concern of criticism. Because of the rules, Pierre Corneille (1606-1684) had to suffer from a hard-headed neoclassical critic, Georges de Scudery (1601-1667).

A resistance to neoclassical rules can be seen in Spain, by a very productive writer Lope de Vega. After discussing elaborately about the rules, by which he seemed to tell his audience that he did know them, he remarked as follows:

But of all, nobody can I call more barbarous than myself, since in defiance of art I dare to lay down precepts, and I allow myself to be borne along in the vulgar current, wherefore Italy and France called me ignorant. But what I do if I have written four hundred and eighty three comedies ... for sometimes that which is contrary to what is just, for that very reason, pleases the taste. (203)

De Vega indicated that rules are fine to know, but what is important is that the plays please the audience. De vega is the first person to mention the audience as having the authority to justify a play. 
Not having to defend its existence, theatre in France and Spain did not come to theological and philosophical dispute. Instead, their debates were more on the artistic level. The "ultimateTruth"/God, therefore, only functioned as a background of artistic discourse. The truth dealt with in the artistic level is whether or not a play is "true to

A bigger rebellion from the neoclassical tradition, however, happened a century later. As in philosophy the humanist renaissance was deeply planted in European thought by the celebration of reason, a new wave of "anti-rationalism" in the arts developed. This movement was delivered by those who called themselves the "Romantics." The romantics believed that art was too much approached from the outside by applying rules to analyze them. It was Schelgel (1767-1845) who said that the current criticism went wrong. "Ordinarily," he said, "men entertain very erroneous notion of criticism, and understanding by it nothing more that a certain shrewdness in detecting and exposing the faults of a work of art" (493). Schelgel proposed that art should be viewed internally since "internal excellence is alone decisive" (494). It reminds us of Longinus who believed in intuition as the source of artistic excellence.

Bringing Aristotle back to the discussion, Schelgel showed that Aristotle had so far been misunderstood by the neoclassics with their concept of Three Unities (505-06). The romantics required "deeper, more intrinsic, and more mysterious unity than with which most critics are satisfied" (508). He also brought back the discussion of Aristotelian organic form with a romantic interpretation: "Organical form, again, is innate: it unfolds itself from within and acquires its determination comtemporaneously with the perfect development of the germ" (510). Truth, therefore, is internal to the romantics. The artist does not imitate life directly as he observes it, but he internalizes it first and then expresses it in a form that might not be similar to that as the senses perceive.

The romanticists did not completely pushed theological truth away. Victor Hugo (1802-1885) explained in the preface of his historical drama, Cromwell, that "Christianity leads poetry into truth" (684). In his appeal to freedom from neoclassic rules he said that the truth is, as God has created, both beautiful and ugly, both sublime and grotesque (687). The internal truth that comes out of the artist, therefore, is related to a more "mysterious" truth that inspires the artist. But the did not necessarily referred to the "ultimate Truth," since they talked about "God's creations." The romantics seem to blend theological, philosophical, and artistic truths in their discourse. Their artistic truth is more of feeling than reason.

Human being's celebration of reason, however, has kept rolling especially with the success of natural sciences as a result of the enlightenment, which have propelled the world to modernism. Scientific inventions started to roll the world much faster than the previous centuries. The propellers were, among others, Darwin's theory of evolution, behavioral psychology, and the invention of steam engine. The invention of steam engine also triggered the Industrial Revolution which forced humanities to think differently about their social structure.

With such a background, Emile Zola (1840-1902) proposed naturalism. Zola thought that theatre was behind for not using the newfound method to uncover truth. "The natural sciences were established, thanks to the minute and thorough exactitude of observation ... each day it revealed a little more of the secret of life" (Zola 695). "They are bringing truth to light in a manner harassing from its rapidity" (695). To Zola, theatre should also use the scientific method of observation/ experiment-hypothesis-analysissynthesis if it was to survive. Referring to Stendhal, he said, "They no longer imagined 
nor told pretty stories. Their task was to take man and dissect him, to analyze him in his flesh and in his brain" (699). In some ways, it was also a stab to the romanticists. Instead of telling "pretty stories," Zola proposed a theatre which presents "a slice of life."

To the naturalists, truth lies in nature and it should be discovered by scientific method. Truth is acquired from the accumulation data that are experimented and observed to reach conclusions. Theatre, therefore, should present life as it is. It magnifies the unseen problem in the society and present it, without pretense, to the audience. Naturalism presents a slice of life on stage under the magnifying glass of the theatre. The truth in naturalism, therefore, is scientific truth. Odd as it might seem, the naturalist's artistic standard is science.

Although the theological truth is out of the picture, it doesn't mean (at least to some modernists) that it has nothing to do with religion. Some historians contend that enlightenment originated from the church, in which some church figures proposed a new approach to religion. They did not want to depend on church dogmas and traditions as the basis of their belief. Instead, they want to pursue logical explanation for it. This was also enhanced by the rise of Protestantism with its emphasis on the freedom of interpretation to the Bible. Although this movement varied greatly, (Some held the fundamental belief, some were of the opinion that religion is not free from scientific pursuit,) this movement works under the assumption that if religion is true at all, it should be subject to scientific examination.

From this discussion we see that theatre does not move linearly. Instead, it moves spirally where at some points the old and the new ideas meet with a different insight. However, it seems that the two threads set out by Plato and Aristotle (especially Aristotle as the world moves to modernism) have always been influential. In the first half of the $20^{\text {th }}$ century, when ideas started to mushroom with unlimited varieties, theatre develops new ideas from realism (which started at the end of the $1^{\text {th }}$ century) to absurdism, or from dramatic (Aristotalian) to epic (Brechtian). The short-lived naturalism was soon challenged and new styles come and go (or change form). Truth is also viewed from different angles, theological or scientific, subjective or objective, intrinsic or extrinsic, to entertain or to educate etc. (It will be interesting to trace it until post-modernity). Whether we can really grasp truth at all we can never be sure. What is sure is that human being's search for truth in theatre is endless.

\section{References}

Aristotle. (1961). Poetics. Intro. Francis Fergusson. New York: Hill \& Wang.

Boccacio, Giovanni. (1974). The geneology of the gentile gods. In Bernard F. Dukore (Ed.), Dramatic theory and criticism. Fort Worth: H.B. Jovanovich Collage Pub.

Castelvetro, Lodovico. (1974). On Aristotle's Poetics. Dramatic Theory and Criticism. In Bernard F. Dukore (Ed.), Dramatic theory and criticism. Fort Worth: H.B. Jovanovich Collage Pub.

Corneille, Pierre. Apologetic letter. In Bernard F. Dukore (Ed.), Dramatic theory and criticism. Fort Worth: H.B. Jovanovich Collage Pub. 
Dukore, Bernard F. (Ed.). (1974). Dramatic theory and criticism. Fort Worth: H.B. Jovanovich Pub.

Gosson, Stephen. (1974). The school of abuse. In Bernard F. Dukore (Ed.), Dramatic theory and criticism. Fort Worth: H.B. Jovanovich Collage Pub..

Horace. (1974). The art of poetry. In Bernard F. Dukore (Ed.), Dramatic theory and criticism. Fort Worth: H.B. Jovanovich Collage Pub.

Hugo, Victor. (1974). Preface to Cromwell. In Bernard F. Dukore (Ed.), Dramatic theory and criticism. Fort Worth: H.B. Jovanovich Collage Pub.

Lodge, Thomas. (1974). A defense of poetry, music, and stage plays. In Bernard F. Dukore (Ed.), Dramatic theory and criticism. Fort Worth: H.B. Jovanovich Collage Pub.

Northbrooke, John. (1974). A treatise against dicing, dancing, plays, and interludes. In Bernard F. Dukore (Ed.), Dramatic theory and criticism. Fort Worth: H.B. Jovanovich Collage Pub.

Plato. (1974). The Republic. In Bernard F. Dukore (Ed.), Dramatic theory and criticism. Fort Worth: H.B. Jovanovich Collage Pub.

Scaliger, Julius Caesar. (1974). Poetics. In Bernard F. Dukore (Ed.), Dramatic theory and criticism. Fort Worth: H.B. Jovanovich Collage Pub.

Schelgel, A.W. Von. (1974). Lectures on dramatic drt and literature. In Bernard F. Dukore (Ed.), Dramatic theory and criticism. Fort Worth: H.B. Jovanovich Collage Pub.

Scudery, Georges De. (1974). Observation on the cid. In Bernard F. Dukore (Ed.), Dramatic theory and criticism. Fort Worth: H.B. Jovanovich Collage Pub.

Sidney, Sir Philip. (1974). The defense of poesy. In Bernard F. Dukore (Ed.), Dramatic theory and criticism. Fort Worth: H.B. Jovanovich Collage Pub.

Tertullian. (1974). On the spectacles. In Bernard F. Dukore (Ed.), Dramatic theory and criticism. Fort Worth: H.B. Jovanovich Collage Pub.

Vega, Lope De. (1974). The new art of writing plays. In Bernard F. Dukore (Ed.), Dramatic theory and criticism. Fort Worth: H.B. Jovanovich Collage Pub.

Zola, Emile. (1974). Naturalism on the Stage. In Bernard F. Dukore (Ed.), Dramatic theory and criticism. Fort Worth: H.B. Jovanovich Collage Pub. 